\title{
Cream plus Pessary Dosage Form
}

National Cancer Institute

\section{Source}

National Cancer Institute. Cream plus Pessary Dosage Form. NCI Thesaurus. Code C149410.

Combination package consisting of a cream and a pessary. 